\title{
Shylock, Shakespeare's Alien (Royal Shakespeare Company)
}

\section{Patrick Stewart}

Marie-Thérèse Jones-Davies (ed.)

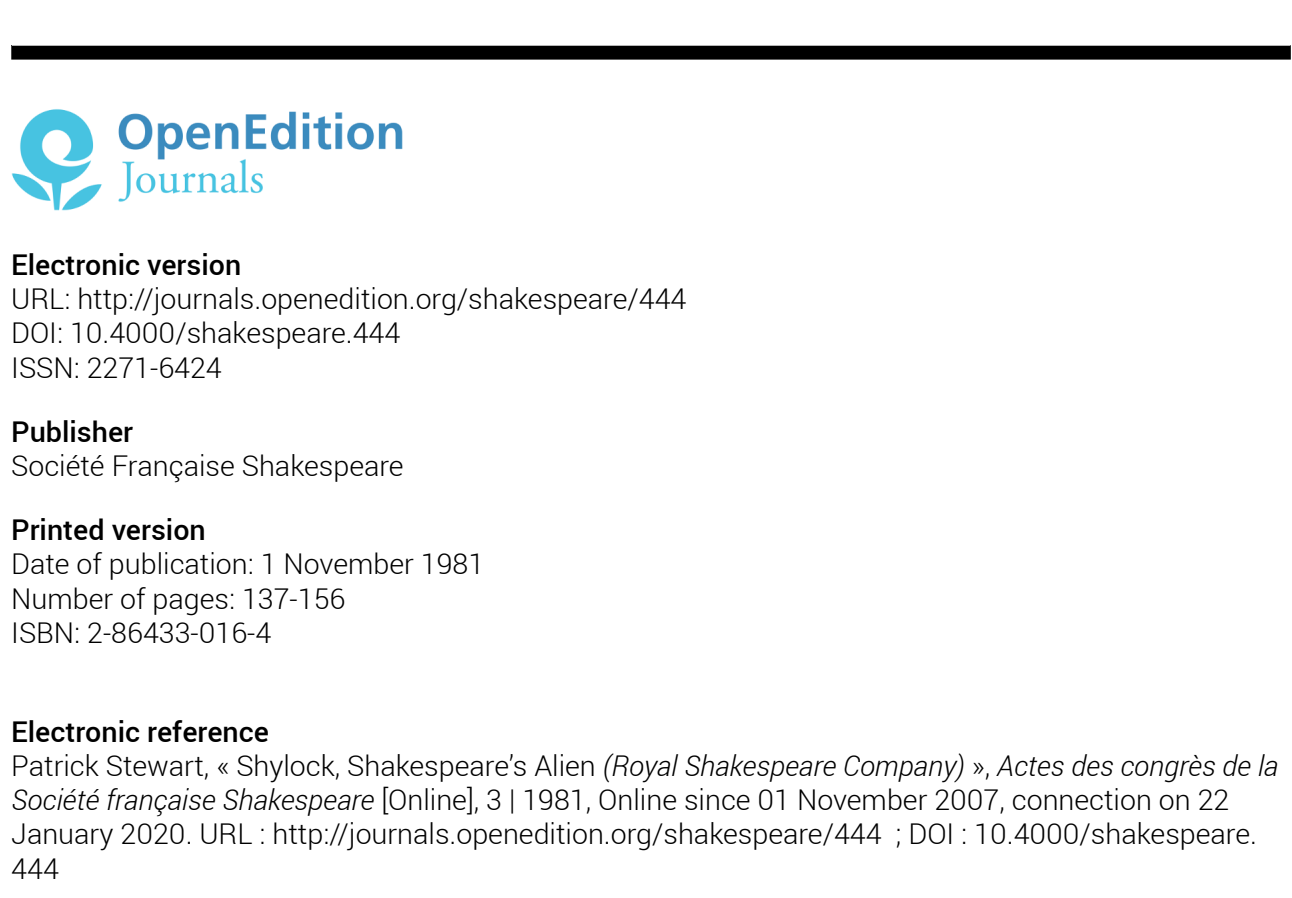




\title{
THEATRE ET IDEOLOGIES :
} Marlowe, Shakespeare

\author{
DIRECTEUR DE LA PUBLICATION \\ M.T. Jones - Davies
}

JEAN TOUZOT Libraire - Editeur

38 , rue Saint-Sulpice 75278 PARIS CEDEX 061982 
1982 Jean Touzot Libiaire-Editeur, Paris.

Reproduction et traduction mzme partielle interdite.

Tous droits réservts potir lous pays

y compris i'U,R.S.S. et les pays scandinaves

ISBN 2-86433-016-4 


\title{
AVANT-PROPOS
}

L'opposition soulignée par Horace entre éthique et esthétique Aut prodesse volunt aut delectare poetae - que les Elisabéthains aiment à évoquer, pourrait être le lien qui rattache les unes aux autres les communications, rencontres et table ronde de notre troisième congrès (1981) sur le thème : "Théátre et Idéologies: Marlowe, Shakespeare.» Toutefois, le résultat de nos échanges montre un dépassement possible de l'alternative éthique / esthétique, puisqu'il met en valeur l'insertion d'idéologies susceptibles de transformer la fonction même de la littérature.

Les pièces analysées dans le contexte de leur temps révèlent de multiples aspects de la vision du monde et de la place que l'homme $y$ occupe, tels que les projette le théâtre anglais au tournant du XVIe et au début du XVIIe siècle.

Une exploration du langage et de la pensée des deux grands dramaturges aboutit à un commentaire sur les courants philosophiques ou religieux, sur les idées parfois contradictoires et sur la curiosité intellectuelle jamais assouvie qui se font jour à travers la rhétorique de la scène et le jeu dramatique, du Faust de Marlowe à La Tempéte de Shakespeare.

\author{
M.T. jones-Davies
}

Présidente de la Société Française Shakespeare 
SOCIETE FRANCAISE SHAKESPEARE Actes de Congrès.1981

\section{THEATRE ET IDEOLOGIES : Marlowe, Shakespeare}

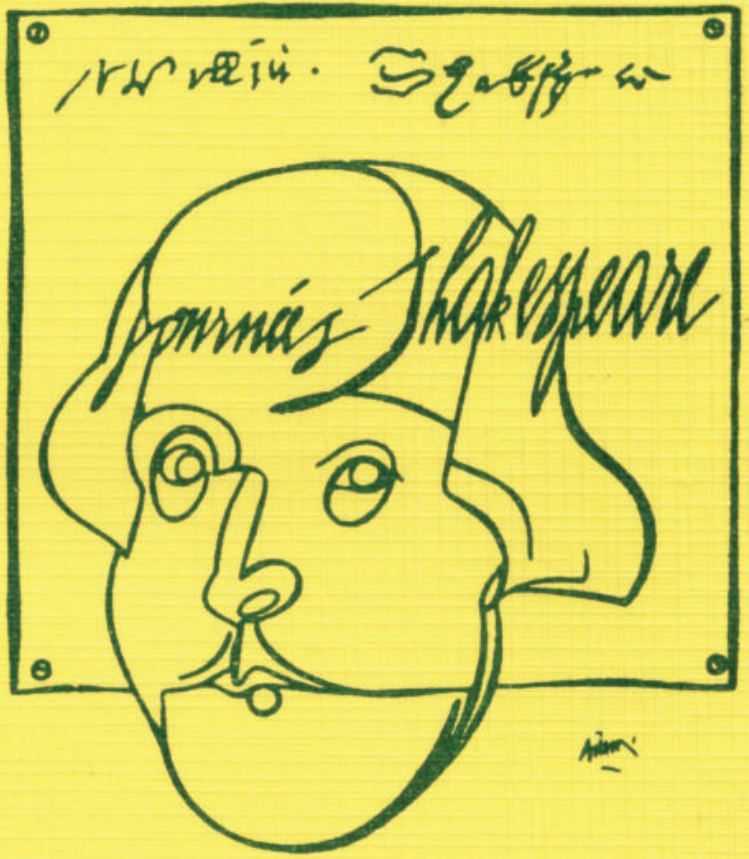

DIRECTEUR DE LA PUBLICATION M.T. Jones - Davies

JEAN TOUZOT Libraire - Editeur 38 , rue Saint-Sulpice 75278 PARIS CEDEX 061982 
Illustration de la couverture : affiche de Valerio Adami, spécialement conçue pour les Journées Shakespeare 1979 au Centre Georges Pompidou 


\section{TABLE DES MATIERES}

M.T. JONES-DAVIES Avant-propos

Théâtre et Idéologies: Marlowe, Shakespeare

S. TRUCHET

The Alchemy of Beauty: aesthetic principles in I Tamburlaine and their relationship to the hermetic ideology.

D. PRUDHOMME

L'idéologie du Juif de Malte et du Marchand de Venise.

D. GOY-BLANQUET

De Hall à Shakespeare : quelques glissements idéologiques opérés par la dramatisation dans Henry $I V$.

M.T. JONES-DAVIES Le Monıde du «si»: Idéologies Incertaines dans Comme il vous Plaira.

G. VENET

Temps et Idéologie : Marlowe, Shakespeare.

J. RICHER

Les Sept Caractères et les Quatre Tempéraments dans Jules César de Shakespeare.

F. LAROQUE

En marge de l'Idéologie : Antimasque et Grotesque dans le Dr Faustus et La Tempête.

A. LECERCLE-SWEET Conscience et Méconnaissance dans Edward The Second de Marlowe.

M.A. CONEJERO Shakespeare's Aesthe tic Scheme. (Extrait).

P.STEWART

Shylock, Shakespeare's Alien.

(Royal Shakespeare Company)

J.RUSSELL BROWN The Romantics' Shakespe are.

R. GILL

The Christian Ideology of Dr Faustus.

J. JACQUOT

Marlowe : de quelques problèmes d'interprétation. 
Rencontres entre Universitaires et Gens de Théâtre

Vendredi 4 décembre 1981
- Stuart Seide :Présentation du

Songe d'une nuit d'Eté. Mise en scène pour le Théâtre de Chaillot janvier 1982

- A propos d'Edouard (II) de

Bernard Turle

Bernard Turle : Métamorphoses de l'auteur et de l'écriture dramatiques. Intervention de Colin Harris (metteur en scène) 


\section{SHYLOCK, SHAKESPEARE'S ALIEN}

«Shylock, in The Merchant of Venice, can be played as a wolfish villain, sadistically lusting for the blood of a Christian he hates. Or, he can be interpreted as a dignified symbol of an oppressed people intellectually and morally superior to the Christians who taunt and abuse him.»

So began one review of John Barton's production of The Merchant of Venice when it opened in London in May, 1979. The production was then a year old, having opened in Stratford in the previous Spring and I had been playing Shylock almost continuously since then. At the time, the unimaginative narrowness of this critic's view of the role appalled me, but had I been more objective, I would have remembered there had been a time, when I would have shared this blinkered view.

The prospect of rehearsing Shylock had not excited me. On the day the part was offered I had felt an irritable disappointment that it was "the Jew» and not a role, bigger and more challenging. I had played the part once before thirteen years earlier and that experience, and other later contacts with the play, had soured my feelings in such a way that I too could only see Shylock as this racial symbol, serving the play with either of these clichéd faces. Intimidated by post war guilt and uneasy and ambivalent feelings about the alleged racist nature of The Merchant, only the sentimental interpretation would seem to be tolerable, and that prospect was only marginally more tiresome than the melodramatic alternative.

Not an appealing prospect. Trapped in the strait jacket of a rigid and predetermined characterisation, suspecting that the part could only be made distinctive and vivid through effects, and faced with all that whath not a Jew eyes» acting, and all that "my daughter and my duckets» acting. And not even "owning» the play, not dominating it. Shylock is a curious role in that its fame and reputation is quite out of proportion with his share of lines. He appears in only five scenes and two of these are very brief. There have been occasions when producers and actor-managers, reacting perhaps to the feeling that the part needed "expanding», have added a sixth scene. The 
scene which might be called "Shylock's return» was added after Act 2, scene 6, and shows Shylock arriving back home to find his house deserted, bereft of daughter, jewels and duckets. Productions develop this scene in different ways. Irving played it very tastefully; a solitary figure crossing a bridge, reaching the door of his house, knocking and waiting in lonely silence as the curtain fell. Fifty years later Herbert Beerbohm Tree had a livelier approach. He stormed through the house, hunting for Jessica and howling at each discovery of the missing valuables. He threw open windows, exhibiting his wild distress, calling his daughters name and finally returning to the stage, tearing his clothes, throwing ashes on his head and falling to the ground. Shylock's role is further diminished by having no appearance in Act 5 and some have resolved this by ending the play with his exit from the trial.

One of the intriguing pleasures of performing a long role, in any play but particularly in Shakespeare, is to feel oneself as the heartbeat of the play; not only caught up in the rhythmic surging movement of the play's energy, but to be the energy itself, the pulse. Like riding a powerful horse; rider and mount are the play. The forward movement is the story and the hoofbeats the rhythm of the language. In performance the actor feels the reins of the play, holding in or giving head as the story moves forward, and the control never being applied in quite the same way twice. For the actor playing Shylock this control is never possible as he spends more time waiting his turn to mount than actually in the saddle.

However, it was not only Shylock's limited share of the play and his stereotyped function that was discouraging for an actor looking for rich, human complexities; but there is even a stereotyped image that goes with the part swarthy, foreign features, invariably incorporating a prominent hooked nose, ringlets, eastern robes (rich or shabby to taste) and clutching either the famous scales or the murderous knife. So strong is this image of the Jew with the raised weapon, that in rehearsals I had to resist the instinct to menace Antonio in this way and throughout the life of the production I felt secretly guilty that I was denying the audience their right to see this traditionnel tableau. I think it was this sense of so much tradition attached to the role that was uninspiring and the fear of finding oneself 
trundling along tramlines, trapped in a lifeless mould. Nevertheless, the actor's curiosity, the mysterious reputation of the role and the intriguing appeal of Shakespeare in the small space of The Other Place combined to persuade me to accept the part. And so I found myself on the threshold of an experience that was for two years to be entirely fascinating and very rewarding.

At my first meeting with the play's director-John Barton - he spoke, briefly, of his feelings about the play and its characters but he said it was a «cool» play, a fairy story and he talked of a sense of melancholy threaded through it. Music would be very important he said (James Walker's lovely score was a marvellous unifier of the play). He and the designer, Christopher Morley, had decided to adapt the auditorium of The Other Place into a "theatre in the round" thus making a set unneccessay and destroying, at a stroke, one Merchant of Venice cliché, the bridge and gondola backdrop. As for Shylock his brief was very simple - he must be a monster. At my first reading I had been delighted to discover how marvellously witty Shylock was, particularly in the early part of the play and so suggested he might be an entertaining monster, and so we shook hands and a bargain. Finally, and with some firmness, he said that he felt that the play had for too long belonged to Shylock, and that this production should restore an equal balance between Bassanio, Shylock and Portia.

This first private reading is very important. Even with a play I know well, it is special and I make a preparation for it is reading the play as if for the first time, leaving the imagination free to react intuitively and simply to whatever the reading suggests. After a long rehearsal period when the play has been so dismantled and probed that the simple elements, such as the story-line or the bold outlines of a character or relationships have become blurred or submerged with elaboration and detail, it is very valuable to remind oneself of those first uncomplicated responses. Shylock's wit and sense of fun was dominant among these.

I have said that I was struck by the wit and rich humour in Shylock. In I.iii he jokes with Bassanio and lightens their opening discussion with a series of puns though rather bad ones. 
SHYLOCK Antonio is a good man

BASSANIO Have you heard any imputation to the contrary?

SHYLOCK Ho no, no, no, no ! My meaning in saying he is a good man is to have you understand me that he is sufficient.

Like an experienced comic Shylock sets up Bassanio with his "good man» and Bassanio, indignantly rises to the bait, only for Shylock to prick his pompous bubble with innocent laughter and his explanation of his commercial use of «good». Then again,

SHYLOCK There be land rats and water rats, water thieves and land thieves, I mean pirates.

and

BASSANIO Be assured you may.

SHYLOCK I will be assured I may.

Shylock's play on words, his highly tuned, ironic sense of double meanings, his use of language as a weapon, or a smoke screen, or an analgesic present an insight into his character. Possibly his wit provides a way of ingratiating himself with the Christian business men, and the irony protects him from the humiliation of being an alien, without losing his self-respect. Does it also suggest this could be someone speaking in a language which is not his own but which he has so carefully assimilated that - like many naturalised foreigners he uses it better than the natives. He certainly employs a colourful and at times bizarre turn of phrase particularly the Jacob/Laban speech in I. iii - and this persuaded me not to use a «foreign» accent as it seemed that the nature of his language itself set him apart. Shylock's good humour is still present after Antonio has entered in I. iii.

ANTONIO Was this inserted to make interest good? Or is your gold and silver ewes and rams?

SHYLOCK I cannot tell, I make it breed as fast.

And in the speech where Shylock describes Antonio's treatment of him, from "what should I say to you", Shylock, with delicious mockery, is turning Antonio's insults back on him.

During my early work on the play I was strongly 
influenced by a repeated theme that is particularly marked in the early scenes. Images of money, commerce and possessions abound and even people seem to have a price. The value of assets and possessions always seems to dominate and colour relationships. This theme where it touches Shylock appears as a series of alternatives for comparison. People, feelings, religion and race versus commerce and material security. Shylock's choices are surprising but - with one exception consistent. This evidence and what it seemed it indicated about his personality became the foundation for my characterisation of Shylock. The principal moments of choice were these.

I. iii. I hate him for he is a Christian; but more for that in low simplicity he lends out money gratis and brings down the rate of usance here with us in Venice.

$\mathrm{He}$ hates our sacred nation and he rails even there where merchants most do congregate on me, my bargains, and my well won thrift, which he calls interest.

III. i. There I have another bad match.

Shylock, who has been discussing the loss of his daughter hears of Antonio's commercial loss and lumps the two together as a «bad match».

III. i. He hath disgraced me and hindered me half a million, laughed at my losses, mocked at my gains, scorned my nation, thwarted my bargains, cooled my friends, heated mine enemies, and what's his reason?

Only one point in Shylock's list of Antonio's wrongs touches on race and religion. The rest is business.

III. i. Why there, there, there, there ! A diamond gone, cost me two thousand ducats in Frankfort !

Shylock's mourning not for the lost daughter, but for the lost diamond.

I would my daughter were dead at my foot, and the jewels in her ear. Would she were hears'd at my foot, and the ducats in her coffin!

Shylock's wish to punish his daughter and to remove her 
shame by having her dead is at one with the return of his valuables.

I will have the heart of him if he forfeits, for were he out of Venice I can make what merchandise I will.

Shylock's justification of Antonio's death is solely and ruthlessly commercial.

IV.i. You take my life when you do take the means whereby I live.

This is not true, but what is important is that to Shylock it seems so. "I am content». With these three simple words and with no dissent Shylock agrees to Antonio using half of his fortune in trust for Jessica and Lorenzo, her Christian husband, to become a Christian, and bequeath his estate to his daughter and his son-in-law at his death.

A picture emerges of a man in whose life there is an imbalance, an obsession with the retension and acquisition of wealth which is so fixated that it displaces the love and paternal feelings of father for daughter, it transcends race and religion and is felt to be as important as life itself. It inhibits him from warm, affectionate responses and isolates him from his fellow man. There is a bleak and terrible loneliness in Shylock which I suspect is the cause of much of his anger and bitterness. This sense of loneliness and how he copes with it became increasingly important to me throughout the life of this production. Indeed, there were occasions when its presence became almost dangerously overwhelming. Of course, it is not loneliness that the actor shows but its compensating aspects. False gregariousness, ingratiating humour, violence and arrogance. Whatever the circumstance of his situation, scene by scene Shylock always stands in isolation. Until, that is, in IV. i., when a young doctor from Rome stands alongside him and seems to take his part. Shylock trusts this support and suffers for it.

But if Shylock's nature is distorted by avarice, what is the cause ? A man does not spring into the world unhappy, cruel and mean. It is his experience of the world, its treatment of him and his attempts to cope, that shape and form or bend and warp him. Shylock and his kind are outsiders, strangers, feared and hated for being different. They belong to the world's minorities. They are, as the laws of Venice 
state, alien, stamped by that world to be always vulnerable and at risk. Therefore survival is paramount. Shylock is a survivor. He has clung to life in Venice and he has prospered. The alien's methods of survival in a suspicious and hostile environment are many. He can go underground and disappear. He can establish a bold and confident public reputation - a dangerous method this. He can abandon all aspects of himself that set him apart and develop a new and conforming identity. Shylock, I believe, has found a way of merging with his surroundings, shabby and unmemorable and if he attracts attention at all, appearing as an eccentric and harmless clown. Only Antonio, his competitor in business, whose senses are sharpened by commerce, smells the contempt that hides behind Shylock's jokes. So in I. iii, Shylock is seen amiably helpful, teasing and playful, a little hurt by Antonio's rudeness but protesting his desire for Antonio's love.

A further aid to survival is money. It will purchase favours and friends, build a wall of protection, buy silence and, in the hardest times, help to maintain a grip on life. It can also create a multitude of dependencies which, being impossible to unravel will prove a true security. In the 12 th century the Jews in England were extremely useful in the economic scheme. Lelyveld wrote : "The Jews of England paid one half of King Richard's 100,000 marks ransom, while the entire city of London was assessed only 1,500 marks. In order to finance the third crusade, the Jews were taxed to the extent of one-fourth of their movable property, while the remainder of the population paid one tenth. Although the Jews constitute only one quarter of one-per-cent of the total population they contributed eight-per-cent of the total income of the treasury ${ }^{1}$. Shylock has perhaps known the vulnerability of poverty - maybe the memory of Leah is linked with it - and from that experience has grown the determination to forge a material security which has, through years of bitter compromise and humiliation, grown into the wretched obsession that possesses Shylock at the start of the play. A feature of this obsession could be excessive meanness. Lancelot claims that he is famished in Shylock's service and in this production he might be believed, as he appeared severely undernourished. Shylock's notion of gourmandising 
might be merely the satisfying of youthful appetite. In II. v, which was set inside Shylock's house, the lighting was so dim as to suggest that most of the lightbulbs, or rather candles, had been removed. As this production was set towards the end of the 19th century it allowed the use of modern props to help establish location, create mood and define character - playing cards, toy pistols, champagne, cigars and cigarettes. Antonio smoked cheroots, Tubal a havana, and Shylock mean little hand rolled cigarettes, whose butt ends were safely stored away for future use. This meanness was carried over into Shylock's appearance which showed an almost studied contempt for neatness or even cleanliness. A shabby black frockcoat, torn at the hem and stained, a waistcoat dusted with cigarette ash, baggy black trousers, short in the leg, exposing down-atheel old boots, and a collarless shirt yellowing with age. Apart from the yarmulke, the only other distinctive garment was a yellow sash, twisted round the waist and only just visible beneath the waistcoat. This ritual-like garment and its wearing was an invention of the designer's though based on photographs of Russian Jews in the 19th century who wore a yellow sash over a long frockcoat. We wanted to avoid any excessive sense of Jewishness or foreignness in appearance but this detail, almost unnoticable in the earlier scenes could, in the court, be boldly worn over the frockcoat as a proud demonstration of Shylock's radical isolation.

In the early scenes I was anxious to minimise the impression of Shylock's Jewishness. Whenever I had seen either a very ethnic or detailedly Jewish Shylock I felt that something was lost. Jewishness could become a smokescreen which might conceal both the particular and the universal in the role. See him as a Jew first and foremost and he is in danger of becoming only a symbol, although a symbol that has changed over the centuries as society's attitudes have changed.

Because of the Nazis' Final Solution and six million deaths, those passages of anti-semitic expression in The Merchant will reverberate powerfully for any audience in this second half of the twentieth century. Actor and director will not need to emphasise them, nor must they be avoided. An audience must witness the intolerance of 
Antonio, the shallowness of Bassanio, the boorishness of Gratiano and the cynicism of Lorenzo. The unease we feel at these characterisations is important. It complicates these men who are at the heart of the romantic story of The Merchant, makes us less happy to accept them or not question their motives. Indeed there is an ambivalence in every corner of the play so that no matter how well a director may bathe Act V in the lyrical wash of romance and fairy tale the memories of cruelty, dishonesty and selfishness will cast troubling shadows across the Belmont dawn. But however important Jewishness and the antisemitism in the play, it is secondary to the consideration of Shylock, the man. Unhappy, unloved, lonely, frightened and angry. And no matter how monstrous his cold-blooded attempt on Antonio's life, it is the brave, insane solitary act of a man who will defer no more, compromise no more. Antonio's life is his line of no retreat,and although justified on commercial grounds, this murder is also, therefore, symbolic. Perhaps this makes of Shylock a revolutionary in modern terms. Certainly, when as Shylock I stood in the court and said "my deeds upon my head" I felt closer to all those oppressed and abused who stand up in the face of a hostile and powerful enemy. This was not one Jew, but all victims who turn on their persecutors. It is in this sense that it seems Shakespeare created a portrait of an outsider who happened to be a Jew. But of course Shylock does step back from the line, he does compromise, he settles for a deal and the patient shrug once more copes with humiliation. In the humble compliance of «I am content» and "send the deed after me and I will sign it», Shakespeare's massive understanding touches the harsh, unsentimental facts of survival. However, this is the end of the Shylock story. And I would like now to look at that story in more detail, noting the major objectives, the motivations, thought processes and imaginative associations that lay behind one actor's interpretation.

Shylock appears in five scenes. Each scene has a quite distinctive quality. One approach would be to blend these qualities in such a way as to present a regular and consistent picture. On the other hand the particular characteristics of each scene can be isolated and individually played without reference to other scenes. This approach relies on the 
conviction that it will not be until the moment of his final exit that the last piece will be added to the puzzle that is Shylock, and the picture completed and truly consistent. I have said that the first scene is rich in humour. There is an extrovert energy in Shylock. He is garrulous, friendly and entirely reasonable. Even before the scene begins, however, Shylock's arrival is anticipated, almost ominously, by Portia's last words at the end of the preceding scene. "Whiles we shut the gates upon one wooer, another knocks at the door». Shylock is not a wooer but Portia's apprehension is well-founded as the next person we shall see will be the play's villain. Perhaps there lies in «knocks at the door» a suggestion as to how «3,000 ducats» should be said. It seems probable that in the off-stage dialogue Bassanio has explained the details of the loan and now Shylock is having him repeat it over, giving no answer but teasing him with each repeated «well». There is too a sense of surprise and pleasure in being approached by Bassanio and Antonio, though this is certainly a pretence. But the speech about Antonio's sufficiency must impress Bassanio with Skylock's knowledge of the merchant's business and the risks involved in maritime trading. This speech is also an opportunity to demonstrate Shylock's quickness of thought and agility with language. He picks up his cues eagerly, of ten impatient for the other character to finish. It is an indicator of his bright intelligence. I saw no sign in the text that he is deliberate, pedantic or ponderous in his speech. Everything points to speed and liveliness. There is more humour in the "pork» speech. A joke about «the Nazarites» and a polite little lecture about the dietary and religious laws of the Jews. This speech is often played as hostile and aggressive but why risk antagonising Bassanio when there are so many intriguing possibilities behind this encounter. Antonio arrives and we move from prose to verse. The contenders are face to face, the tone of the scene shifts and becomes more tense. Verse is needed now and the change of rhy thm must be apparent in Shylock's aside. Here are no games, no jokes, but bitterness and resentment. It is a speech to the audience, therefore the truth, and they should be shocked to see this change. Shakespeare permits the audience to taste Shylock's real feelings so that they will see through the 
play-acting that is to follow. It is interesting that Antonio begins by justifying his involvement in this deal. It is for a friend, but he is clearly embarrassed. This makes him vulnerable and Shylock knows it. So the teasing and the mockery begin. The Jacob speech is very characteristic of Shylock. A colourful and witty justification of thrift and sharp dealing. Shylock also plays the «amusing storyteller" but Antonio is not amused. His response is crude and insulting. Has Shylock merited "devil», «evil soul», "villain", «rotten at the heart» and "falsehood»? Here is a sure sign of Antonio's discomfort and embarrassment. How does Shylock react? How do the persecuted invariably react ? With «a patient shrug». But Shylock's passive acceptance is a goad to Antonio and he angrily demands an answer. Shylock's response is a masterly piece of controlled and brilliant irony. He is saying : «Signor Antonio, I am puzzled. You abuse me for the way I make my living and $I$ understand that, and can put up with it. But now I am confused because you want my professional help and I don't know how I should react to you. Please tell me what is right, what I should do?». Antonio cannot live with that level of complexity and he clubs his way back to a simple hostility that makes him feel secure. Shylock, still sympathetic, talks of friendship and love, but baits his hook with mention of an interest-free loan. And still the puns continue; "This is kind I offer». Bassanio, quick to sense something for nothing, bites. And Shylock, in one swiftly flowing, innocently spontaneous sentence, delivers the final mock of the flesh bond. And mockery is all it is. Shylock, knowing the extent of Antonio's wealth could not dream that he would fail so dramatically. He will help his enemy but his hatred will publicly show itself in the humiliating clause of the pound of flesh. Shylock teases them about their suspicion and daringly inserts a final mock about the flesh of muttons, beefs and goats being more estimable than Antonio's, though once again softened by words of friendship and love.

For most of the scene the audience should have enjoyed watching him enjoying himself. Here is an entertaining eccentric we look forward to seeing again. But before his exit a private shadow passes across Shylock as he mentions his house and that shadow will soon blot out 
the cheeriness of I. iii.

II. v. is Shylock's only private scene. The others are all public and as such Shylock is on show, conscious of possible observers and the effect he is having. In II. v. there is no need for a public face and the unrestrained man will emerge. There are only two references to life in Shylock's house, and though they come from different people they are complementary, and present an appaling picture. "The Jew my master is a kind of devil». "The very devil incarnation» "I am famished in his service». Jessica says simply and bleakly "Our house is hell». This, I felt, is the description that II. v. has to live up to. It is not the hell of poverty or meanness or even cruelty, but the hell of a house from which love has been withdrawn. This is the hell that Jessica flees from to give herself to the (questionable) love of Lorenzo. Young Gobbo is leaving and is sneered and snarled at while Jessica is called with an impatience that grows dangerous. She is treated like an incompetent servant and the mention of masques releases Shylock's suppressed, sour anger, the anger of resentment - resentments of a lifetime that each day grow more bitter, but only within the walls of his home can this anger be released. The joker of I. iii. is here appalled at the thought of the drum and the fife and in V. i. Lorenzo tells Jessica that «The man that hath no music in himself, Nor is not mov'd with concord of sweet sounds, Is fit for treasons, stratagems, and spoils; The motions of his spirit are dull as night. And his affections dark as Erebus.Let no such man be trusted». There is violence in Shylock as well as anger. Jessica is too eager to take the keys - the keys that will unlock the ducats and jewels as well as secure the house - and when Shylock looks into her face he sees, without understanding, defiance and rejection. That look terrifies him and it has to be erased. There is no love to remove it only a vicious slap across the girl's face, humiliating both father and daughter. "Perhaps I will return immediately" attempts to soften the blow, but a great gulf has opened between them and Shylock falls back on empty maxims. This was consistently the most satisfying scene to play.

When Shylock arrives at the great scene of III. i. Shakespeare has prepared the audience for his condition 
and has done half the actor's work for him with Solanio's description in II. viii of his outrageous and uncontrolled passion at the loss of daughter and ducats. The intensity of this passion cannot be sustained and Shylock must be exhausted by his experience and very vulnerable. There is a plaintive, complaining tone about his first speeches and little threat in the repeated "Let him look to his bond». To Salerio's question, "Why, I am sure, if he forfeit, thou wilt not take his flesh. What's that good for?» Shylock can only reply, "To bait fish withal». But out of this hour of frustration develops Shylock's most well known speech. In rehearsals its reputation inhibited me. I stumbled unhappily through a quicksand of famous quotations, received impression of how the speech was about injustice, compassion, radical tolerance, equality and the evils of bad example. The difficulty was that interpreted this way the speech seemed to come from another play and had little connection with the Shylock of the earlier scenes. This reading, though fitting in parts, did not seem to be serving Shakespeare and made me very dissatisfied. At this point two things happened. I began to focus my attention on that word repeated four times-«Revenge» and I was lucky enough to see a paper by Professor Alan C. Dessen which dealt with the very heart and matter of this speech.

A.C. Dessen writes «Many of the morality plays of the 1560 s and 1570 s were concerned with the impact of materialistic values upon Christian society. To set up their dramatic sermons, however, such moral dramatists apparently did not resort to the stage Jew but instead brought on stage obvious ethical alternatives embodied in contrasting figures like Worldly Man and Heavenly Man or Lust and Just. At least three extant Elizabethan plays, however, do use the obvious stage Jew to indict false Christians. The earliest and simplest example is Robert Wilson's Three Ladies of London. The only scenes not set in London involve Mercadorus, a merchant who worships Lucre, and Gerontus, a Jewish moneylender. At their first meeting, when the merchant postpones payment of a long-standing debt, Gerontus observes that if Jews should deal so with each other, no one would trust them, yet "many of you Christians make no conscience to falsifie 
your fayth and breake your day». Christopher Marlowe's Malta is many leagues from Wilson's London, yet his use of the stage Jew sets up an analogous indictment of a Christian society. Thus, at the outset of the play Barabas states openly that he would rather be hated as a rich Jew than pitied as a poor Christian; commenting sardonically upon Maltese hypocrisy, he observes : «For I can see no fruits in all their faith, but malice, falsehood, and excessive pride, which methinks fits not their profession». By the end of Act II, we can at least understand Barabas's argument that "it's no sin to deceive a Christian" for, in practice, he is merely following Christian example. In The Merchant of Venice Shylock throws down a challenge to Christian Venice quite similar to Barabas's indictment of Christian Malta : «if you prick us do we not bleed ? if you tickle us do we not laugh ? if you poison us do we not die ? And if you wrong us shall we not revenge ? - If we are like you in the rest, we will resemble you in that. If a Jew wrong a Christian, what is his humility ? Revenge ! If a Christian wrong a Jew, what should his sufferance be by Christian example - why revenge ! The villainy you teach me I will execute, and it shall go hard but I will better the instruction». Barabas, we should remember, had justified his villainy by arguing that "Christians do the like». Here Shylock, in similar fashion, defends his pursuit of Antonio's pound of flesh by appealing to "Christian example». According to this argument, the villainy about to be executed by the Jew has been taught him by vengeful Christians who in their practice show little humility or sufferance. Shylock's promise to "better the instruction" is therefore the statement not only of a stage villain but also of a good student who has mastered his lesson. At the start of the famous trial scene Shylock can still forcefully attack the hypocrisy of Christian Venice, this time using as evidence the institution of slavery. As in Marlowe's II. iii. Shakespeare uses slavery to call attention to the gap between Christian profession and Christian practice, especially by having Shylock apply such terms as "ours", "mine», and "dearly bought» to human beings or human flesh. After listening to this blunt account of the slavery practiced in Venice, we do not condone Shylock's vindictive treatment of Antonio but we are made aware of «Jewish» 
values in a supposedly Christian society. In his possessive attitude toward his enemy's flesh, this stage Jew is bettering the instruction provided by the Venetians while calling attention to Christians in name but not in deed on and off stage».

"What then are we to conclude about the stage Jew as presented by Wilson, Marlowe, and Shakespeare ? Although initially the three plays seem to have little in common, in each the same distinctive stage figure has served a comparable function - not merely to vilify Jews and Judaism but to challenge the professions of supposedly Christian London or Malta or Venice. By viewing Gerontus, Barabas, and Shylock as dramatic kinsmen, the modern reader can grasp the convention that stands behind them and informs them. In morality play, tragedy, or comedy, the stage Jew could function as a dramatic scalpel with which the Elizabethan dramatist vould anatomize the inner reality of a society Christian in name but not necessarily in deed. The fact remains that Shakespeare did choose as his villain what seems to us an objectionable stereotype, but by recognizing the stage Jew as a potential theatrical device (and not a direct expression of authorial bigotry) we may be able to sidestep Shakespeare's alleged anti-semitism and instead appreciate the artistry with which he has incorporated such a stock figure into the world of romantic comedy $"{ }^{2}$

Here was the insight that transferred that speech from a muddled and sentimental bit of humanism to a vigorous justification of revenge by Christian example. And yet all this is only rhetoric as Shylock has yet to hear the confirmation of Antonio's failure.

Tubal has not found Jessica in Genoa and in his grief and loss Shylock pitifully blurs the distinction between daughter and ducats, and wretchedly complains about the cost of searching for her (At "And I know not what's spent in the search», Tubal presented his bill of expenses which included, in writing just too small for the audience to read, a huge bar and restaurant bill for two nights at the Genoa Hilton). Shylock becomes almost hysterical as he crashes from deep despair to wild elation at the alternating news of Jessica's profligacy and Antonio's losses until he hears of the exchange of Leah's ring for a monkey. 
Here is something that cannot be priced, that «a wilderness of monkeys" cannot equal, beyond value. A simple gift, possibly a betrothal ring, from a woman to her lover. "I had it of Leah when I was a bachelor». That word shatters our image of this man Shylock and we see the man that once was, a Bachelor, with all the association of youth, innocence and love that is to come. Shakespeare does not need to write a pre-history of Shylock. Those two lines tell us so much. At this deepest moment of sorrow Tubal confirms that Antonio is utterly vulnerable, and now Shylock decides to kill him. No single incident or word is entirely responsible, but it is certainly Leah's ring and Shylock's confusion of love and grief that is the trigger. Shakespeare's choice of a name for Shylock's wife is interesting. John Russell Brown in the Arden Shakespeare points out that in Hebrew Leath means «Painful» or «Wearied». Shylock and Tubal will meet at the synagogue and it is there that the "oath in Heaven" will presumably be made.

When we next see Shylock the oath and the bond are public knowledge and, almost revelling in the general condemnation, Shylock chants and howls his murderous intention abroad. I felt there was a wildness about Shylock here, shown by the repetition of "I'll have my bond" and the refusal to let Antonio speak, as if the anticipation of his deed has made him mad. This is the man that the unsuspecting Portia is preparing to meat.

Act IV scene $i$ is often referred to as the trial scene or court scene. In fact it is neither. No one is on trial and there is no formal court - in the legal sense. It seems to be much closer to a hearing in chambers or a final, private appeal before the highest authority, the Duke. There is no Judge and Portia is there as a legal expert, to advise the Duke and pronounce on law. Only those characters necessary to the action need appear (In Charles Kean's production in the 1850 s this scene had no fewer than twenty. six judges and forty senators ". $^{3}$

What a change there is in Shylock from the previous scene. He listens calmly without interruption to the Duke's speech, although it is not without provocation, and waits until he is invited to speak. In John Barton's production this mood of calm politeness and restraint was emphasised 
by the Duke himself serving Shylock with coffee. When at last he speaks, he is once more the controlled, articulate, witty man of III. i.. His words are almost apologetic, at first, though quickly growing firmer. The speech becomes mockingly rhetorical, however, when he calls the cutting of Antonio's flesh a whim, and will not justify himself more than one needs over a troublesome rat, a gaping pig, a cat or a bagpipe. It's just a simple impulse, he says, like urinating. So a man is going to be killed but it is not important enough to give a reason, except perhaps, that he is hated and loathed. Shylock is not going to waste this hour of triumph. The knife will be twisted many times before it enters Antonio's body and everyone will suffer. Bassanio takes Shylock on, but is brushed aside like a troublesome fly. Antonio alone understands what Shylock is about and with fearless contempt towards him, he urges the sentence. Bassanio, judging others by himself, is still convinced that Shylock has his price, waves ducats in his face, and the Duke talks of Judgement day, but this cannot frighten Shylock who can again cite Christian example as his security. In this speech there is marvellous evidence of the reason why Shylock is such a troubling character for an audience : deeply critical of society's cruelty, a truly humanist argument, but used to justify more wickedness. This speech returns to judgement at the end, but this time of the here and now variety. The Duke threatens to dismiss the court and Shylock is alert at once. He will, of course, expect the Christians to trick him or slip out of their responsibility and he must watch their every move.

Shylock sharpening his knife is the black humourist at work again. Antonio is being stoical and nobie, and Shylock's response is the crude reality of cold steel. It's just possible that it is also meant to frighten Nerissa. Gratiano thinks it will help to call Shylock an inexecrable dog and talk unhallowed dam, but Shylock politely refuses to be provoked. Instead he gives all his attention to Bellario's letter and the news of a "young and learned doctor". This could be the Christian's trick. Portia appears and Shylock becomes withdrawn and defensive. He gives nothing but his name and when again mercy is proposed Shylock tests this young doctor's quality with a simple "why». Her answer is well known. It is a good speech, but 
I am convinced that what makes it remarkable in performance is that it is pure improvisation. Any interpretation that is at all pre-determined will turn it into a tract. Portia proposes mercy because her upbringing and nature cannot conceive of any other response to someone in such difficulty. She has never imagined that anyone could ask "why mercy ?» or that such a person could exist. She is invited to justify something which is as natural to her as breathing and it is the shock of that that motivates «The quality of mercy is not strained", and we are moved as we hear her articulate her faith, perhaps for the first time. I believe that Shylock too is moved by her words and that is why he has to dredge up the terrible oath «My deeds upon my head». Bassanio is still offering more money, (Portia's presumably) and bits of himself he is never likely to have to pay, but when he begs the Duke to twist the law, «to do a great right, do a little wrong» we see the real slippery opportunist at work. This is what Shylock has been expecting though perhaps not quite so crudely proposed. Portia's response, therefore, is utterly unexpected. Suddenly she is standing by his side supporting him. The Venetians'legal lackey turns out to be honest. Shylock is euphoric and for the first time in the scene he loses control. He stops thinking, watching and listening and his defenses drop. Had he continued to think he would have known this «honest» person would not let him take a man's life. Had he truly listened he would have heard her continue to urge mercy as before, and had he watched her face, he would have seen her struggling to save him from the blows that are to come. She even allows Shylock a glimpse of her trump card - the blood clause - by indicating that Antonio may bleed to death, but at last she hardens her heart against Shylock when he refuses to provide a surgeon to stop Antonio's wounds. Shylock has set himself up and the thunderbolts are about to fall.

Bassanio and Gratiano would see their wives dead if it could save Antonio's life. Hollow words again but interesting for Portia and Nerissa to hear.

The sentence is given and Shylock moves in to carry it out and the trap closes.

In the past I had been puzzled by the speed at which Shylock slams into reverse, from «A sentence, come 
prepare» to «I take this offer then». If the interpretation is heroic or sentimental I don't know how the actor does it. If it's pragmatic, then it's easy. Shylock is told he will lose his lands and his goods. Portia plays the blood card. Shylock immediately sees the (expected) trap he has walked into, considers for a moment what he will lose, checks the law, and knows at once that he must back off. What is delightful about Shylock at this moment is, that though under threat, he still tries to make off with three times the value of the bond. Portia is stubborn and Shylock, not really understanding her, and thinking himself back in the market place, tries to bargain with her. He will settle for his principal. Now, however, the experienced survivor begins to smell real danger and he knows he must put distance between himself and this place, but the ground is opening up beneath him and when the word "alien" hits his ears he knows he is to be finished off. Once again he is an outsider, without rights and utterly vulnerable. This is no place for pride or heroics. Shylock knows if he wants to survive he must get down in the dirt and grovel. So his life is pardoned. He howls and whines and he gets back half his fortune. They want him to become a Christian and bequeath his estate to Lorenzo and Jessica and he is content because he has saved something when moments before he had nothing. Now he must get away before they change their minds or think up further punishment. Illness is a good excuse and he leaves them with the assurance that the deed will be signed.

Every actor playing Shylock looks for an effective way to "get off». Kean apparently went through a startling physical change on his exit. Edwin Booth invented an elaborate and melodramatic mime. Irving was still and tragically defeated, letting out a long sigh as he left and recently Laurence Olivier left his effect for of fstage when, after a moment of silence, the audience heard a despairing howl of grief and rage. Here Gratiano provided the clue. He makes a cruel joke out of Shylock's christening and the person who must laugh most is, of course, Shylock, and so he leaves.

It saddened me that people were upset by the squalor of Shylock's ending, rather than angry that it should be necessary, but I am much more moved by the tragedy of 
"You take my life when you do take the means whereby I live», and the humiliation of «I am content».

Shylock is a very great and tragic role and its power over actors and audiences alike may be in part because he is not a king or tyrant or great lover, but a small, complex, real and recognisable human being, part of us all. The role took me by surprise and taught me an important lesson about the foolishness of coming to Shakespeare with preconceived ideas. Everything I once felt about the part was turned upside down and I became a passionate enthusiast where I had been a cynic. In one sense it was a rare incidence of having an identification with a character, which went beyond acting well. Someone once said that it was necessary for an actor to love the character he played, however evil. I loved Shylock and feel that it was a privilege to be given an insight into such a life.

Patrick STEWART

\section{NOTES}

1. Toby Lelyveld, Shylock on the Stage, London, Routledge and Kegan Paul, 1961, p. 5 .

2. Alan C. Dessen, «The Elizabethan Stage Jew and Christian example, Gerontus, Barabas and Shylock», Modern Language Quarterly, vol. 35. No 3, pp. 234-244.

3. T. Lely veld, ibid., p. 45 . 